\title{
Spatial distribution of slums and its association with disaster vulnerability in Yogyakarta City
}

\author{
Djaka Marwasta* and Theresia D. K. Rahayu \\ Department of Environmental Geography, Faculty of Geography, University of Gadjah Mada, Indonesia
}

\begin{abstract}
Slums commonly distributed in susceptible environment or in location that occupied by low economic household, especially in urban areas. Empirically, in Indonesia, the data about distribution and total area of slums is quite hard to be acquired, since slums indicators is not standardized yet. This study aimed to (1) identify the distribution of slums in Yogyakarta City, based on multi-sources data; and (2) elaborate the linkage between slums location and disaster vulnerability in research area. This research uses a mixed methods, i.e utilization of secondary data, survey method, and GIS mapping. Analysis units of this research are "Kelurahan", where all "Kelurahan" which have slums are chosen as members of population (census technique). Indepth interview conducted in order to collect disaster vulnerability data in each "Kelurahan". Informant that chosen as representative person in each "Kelurahan" are "Lurah" or "Secretary of Lurah". All of the data are analyzed by qualitative and quantitative descriptive method. Conclusion of this study are: (1) Slums in Yogyakarta City distributed mainly along three main rivers, and (2) There are very closed association between slums area and disaster vulnerable zones.
\end{abstract}

\section{Introduction}

An increase in the proportion of urban population has led to the development of slums [1]. During the last two centuries the proportion of the world's population living in cities grew from around $5 \%$ to $50 \%[2,3,4]$. Rapid urbanisation growth triggers the emergence of slums in urban areas $[5,6]$.

The high demand for settlements, while the land availability is very limited, makes the provision of land for settlements and it's infrastructure difficult to do [3], [7]. This phenomenon has triggered the emergence of slum and squatter settlements, especially in urban areas $[8,9]$. The majority of residents occupying slums and squatter settlements are middle-to-lower income groups $[10,11]$. The condition of the house and its environment is very improper as a residence, whereas according to Housing and Settlement Laws of the Republik of Indonesia, Article number 1 of Law No. 1 Year 2011, the house is a building that functions as a habitable residence, means of fostering family, a reflection of the dignity of its inhabitants as well as assets for its owner.

Slums are defined as areas that have high population density and do not have adequate access to drinking water and sanitation, low quality residential buildings and unclear housing ownership [4]. Slums also defined as neglected parts of cities where housing and living condition are appalingly poor [12]. Furthermore, slums also defined as a contagious settlement where the inhabitans are characterised as having inadequate housing and basic services [1]. Even no one definition of slums can be satisfactory, generally slums related to two issues, (1) slums is a multidimentional construct, and (2) slums is a spatial entity.

Yogyakarta City has a number of slums area spreaded across 13 sub-districts. Refers to the Decree of the Mayor of Yogyakarta City No. 216 of 2016 concerning Determination of Slums Existing Zones in Yogyakarta City, there are 35 "kelurahan" in 13 sub-districts have a slums area with a total area of $264.90 \mathrm{Ha}$.

The problem of slums is closely associated with environmental conditions [13]. The problem that was also examined in this research is how the relationship between the distribution of slums and the level of disaster vulnerability in the study area. Slums can decrease the quality of the environment, and the quality of people life as well [14]. This can lead to disaster vulnerabilities, both natural and social disasters $[15,16]$. The emergence of negative impacts of slums to dwellers and the environment causes the need for maintaining slums areas in order to improve existing settlements quality. Coordination between Communities and Government is needed due to improve slums condition.

One problem that has occurred so far related to slums issues in Indonesia is the lack of valid data, and it caused inaccurate policy to be taken by government. This study tries to incorporate data from survey method (primary data), institutional publication (secondary data), and GIS mapping method. This study aimed to (1) identify the distribution of slums in Yogyakarta City, based on multi-

\footnotetext{
* Corresponding author: jakamar@ugm.ac.id
} 
sources data; and (2) elaborate the linkage between slums location and disaster vulnerability in research area.

\section{Methods}

This study was employed survey method, secondary data analysis, and mapping with GIS technique. Survey method was conducted due to collect primary data by using indepth interview. Institutional publication was established in order to compile data about policy and disaster occurrence in study area. Meanwhile, GIS teqhcique is used to identify the distribution and growth of slums.

Research method used in this research is mixed method (qualitative and quantitative). Study area is chosen base on the consideration of the number of slum areas are still dominant. All "kelurahan" that still have slums (35 kelurahan) were selected as research population, so this study using census research method. Head of "kelurahan" or so-called "Lurah", or "Secretary of Lurah" was chosen as the informant in the indepth interview. Thus, the number of informants is 35 persons.

In addition to primary data, this research also requires secondary, i.e topographic maps in scale 1: 25,000 (RBI map) and publication data from Yogyakarta City in Figures 2019. Scoring and calculation of composite indexes is chosen as data processing technique. Based on scoring and composite indexes results, data is analized descriptively, and then presented in graphs and maps. The scoring method is employed into both secondary and primary data. The score are 1,2 , or 3 , where 3 is the highest value and 1 is the lowest.

The results of scoring technique on each variables are processed by using a composite index calculation due to get an equivalent value in environment, social and economic aspects. The smallest value of composite indices is 0 and the highest value is 1 . The index on each aspect measured in each "kelurahan" as mentioned above. Furthermore, composite index on social, environmental and economic aspects in each "kelurahan" is classified into slums index. The slum index is expressed on a scale from $0-100$ with 0 being the lowest value and 100 being the highest value. The slum index used is grouped into four categories as in Table 1.

Table 1. Slums index Categorisation.

\begin{tabular}{|c|c|}
\hline Index Value & Category \\
\hline $0-25$ & Very bad slums \\
\hline $26-50$ & Bad slums \\
\hline $51-75$ & Moderate Slums \\
\hline $76-100$ & Slightly Slums \\
\hline
\end{tabular}

In other hand, the occurrence of natural hazards that frequent happen in each "kelurahan" also be identified. By using GIS analysis, disaster vulnerability maps was made. Scored and indexes techniques also applied in that kind of analysis. Finally, comparison between slums spatial distribution maps, slums index maps, and disaster vulnerability index maps are overlaid in order to produce slums meanagement rank maps. Pursuant to the final maps, relation between slums distribution and disaster vulnerabilty distribution was analyzed descriptively.

This study also employed SPSS 19.0 software and ArcGIS 10 due to process and analyse the data. The results are presented in tables, graphs, diagrams, and thematic maps. Research framework flow diagram presented in Figure 1.

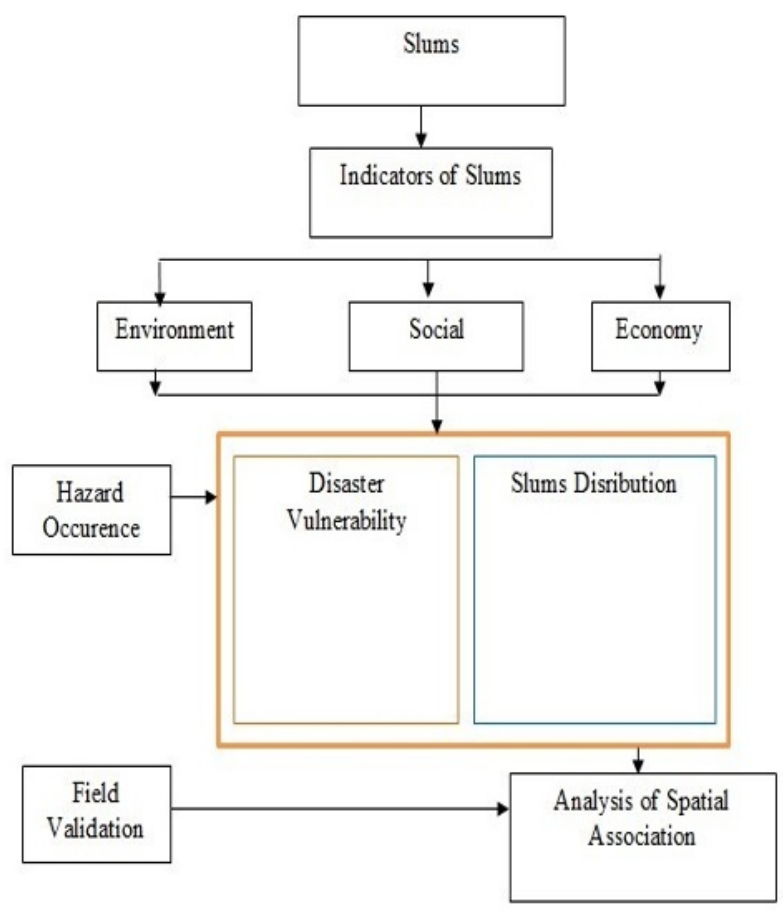

Fig 1. Research framework flow diagram

Slums is principal issue in this study. Due to identify slums existence, it need to determine some indicators. According to SDG's concept, they are 3 indicators has to be entangled, i.e environment, social, and economic. Slums spatial distribution are extracted from 3 aspect by scoring and indexing. In other side, Hazard occurences in the past is used to specify disaster vulnerablity. And finally, analysis of spatial association can be conducted.

\section{Results and discussions}

According to Marwasta study, and recent condition mapping which was obtained by remote sensing data and field observation, total area of slums in Yogyakarta tend to growth lineary [3]. In every ten years, total area of slums increased $25 \mathrm{Ha}$, except in the period 1980-1990 (See Figure 2). Refers to population growth that occured in same periods, it is a big surprise that slums areas increased much higher. Average population growth was just at least $0,5 \%-1,5 \%$ annualy, but total slums areas growth almost $25 \%$ annualy. Thus, development of slums in Yogyakarta City was not driven by population growth, nor urbanisation rate. 


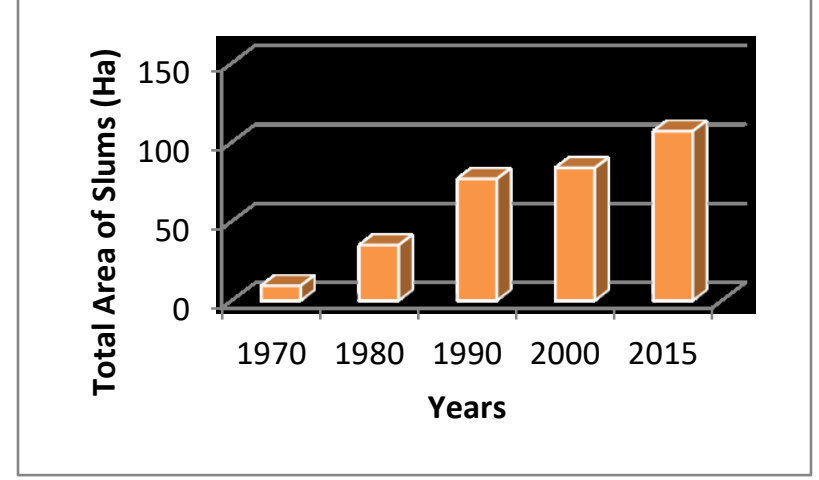

Fig 2. Total Area of Slums Trend Graph

Spatially, slums in Yogyakarta City spread lineary. Slums was distributed along 3 main rivers, they are Winongo, Code, and Gadjahwong River. Figure 3 shows spatial distribution of recent slums zone respectively. Refers to the study was done by Marwasta, this spatial distribution is not change since 1970 as yet [3].

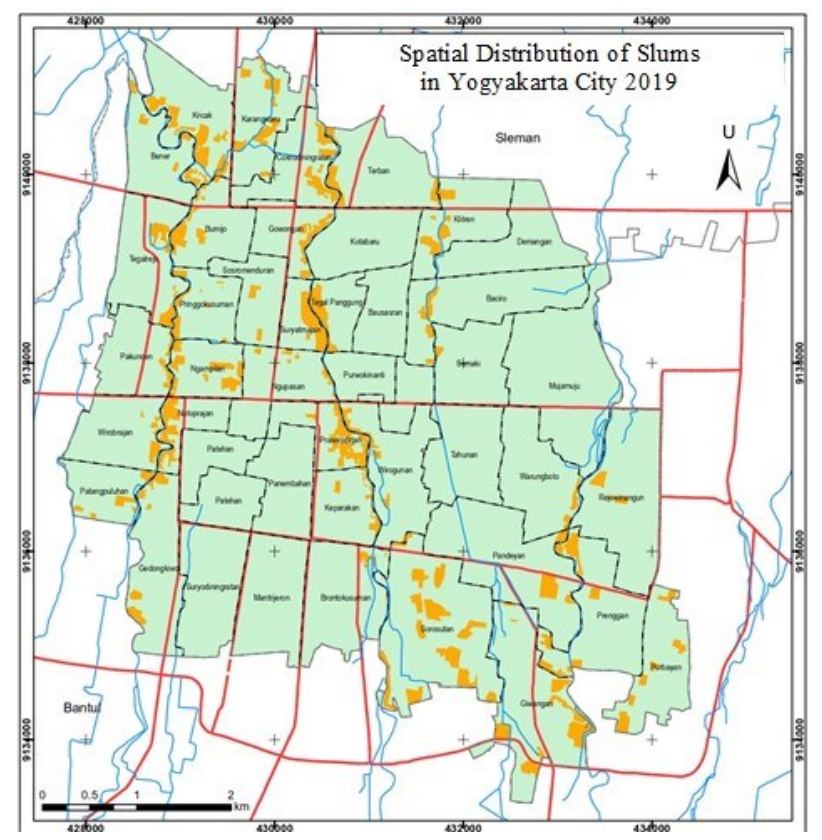

Fig 3. Recent Spatial Distribution of Slums

It is no wonder that spatial distribution of Slums in Yogyakarta City follow the rivers line pattern. Land that located adjacent to river are the most often encountered place where slums is found. That location has cheapest values, and poor people can only afford land in city there. Mostly, people who live in slums area are poor people, and have no access to worthy location for settlement.

To find out in detail about the conditions of slums, an assessment of 3 aspects was carried out, i e environmental aspect, social aspect, and economic aspect. The use of that 3 aspect refers to the concepts of sustaibnable development. In each aspects, this study employ several variables.

The indicators of environmental aspect which used are roads, drinking water supply, drainage, waste water management, solid waste management, fire safety and public open space. All variables are scored, and be calculated as index. Based on scoring and indexing result, condition of environmental aspect in slums area is showed in Figure 4. Dominantly, environmental condition in slums area was moderate class, while proportion of good and bad category for each was at least $24 \%$.

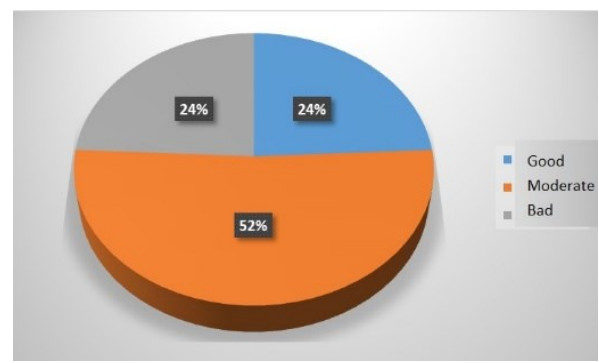

Fig. 4. Proportion of Environmental Aspect Condition

Spatial distribution of environmental indexes in each "kelurahan" is showed in Figure 5. It is seen that bad cateory of environmental aspect scattered a bit equaly along 3 main rivers. They are west side of Winongo River (Bener and Gedongkidwo), west and east side of Code River (Tegal Panggung, Suryatmajan, Prawirodirjan, and Wirogunan), and also west and east side of Gadjahwong River (Klitren and Baciro).

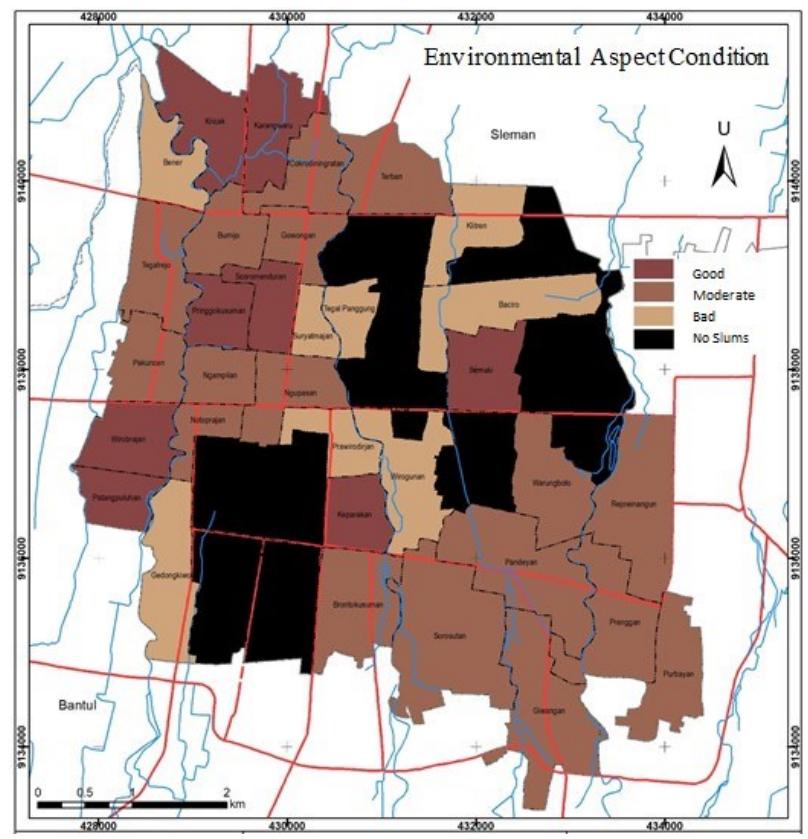

Fig 5. Spatial Distribution of Environmental Aspect Condition

An important dimension that determines the conditions of slums is social aspect of residents. Measurement of social aspects in each slums area is carried out by measuring the level of participation of the community, non-governmental organizations, and village officials.

The community plays an important role in the social aspect because they are getting direct contact with the surrounding environment. Problems faced by the community that not be solved, then, were discussed in the Non-Governmental Organization forum. Nongovernmental organizations are a driving force for community awareness, as well as playing a role in 
monitoring and supporting community welfare. All activities of communities and non-governmental organizations are coordinated by local government (kelurahan) officials.

Concerning to social aspects of slums assesment, 3 dimention as mentioned above, was scored and endexed into 3 categories. The proportion of each categories is presented in Figure 6. As shown in Figure 6, moderate category has highest proportion, follow by good category, and the last is bad category. It is indicate that social participation in slums area relatively good. While be compared with environmental aspect, social aspects category is quite better.

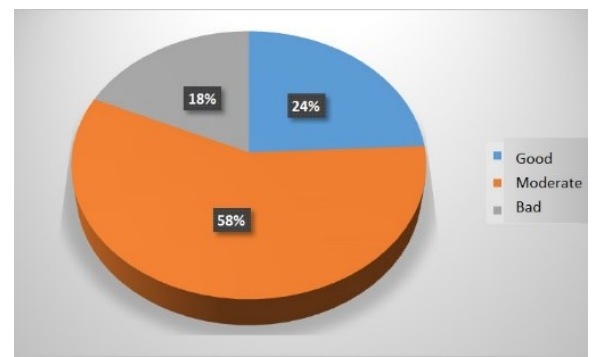

Fig 6. Proportion of Social Aspect Condition

Figure 7 shows spatial distribution of social aspect indexes in each "kelurahan". Bad cateory of social aspect dispersed mostlhy in southern zone. They are Notoprajan, Gedongkiwo, Keparakan, Pandeyan, and Prenggan. The only "kelurahan" that located in northern part is Klitren.

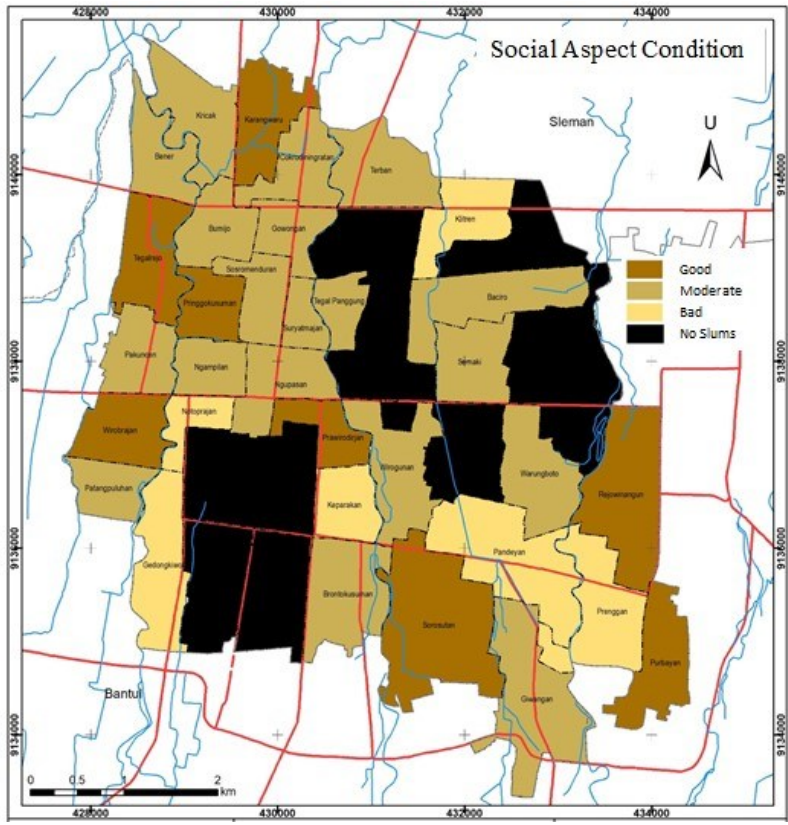

Fig 7. Spatial Distribution of Social Aspect Condition

The third aspect that determined slums condition is economic aspect. Economic conditions of household affect to slums condition, where people have a tendency to meet their primary needs first before using them for other needs. The more poor of household, the more probable to bad maintain their settlements, and very potential to be bad slums.
Economic aspects which used is poverty level that is derived form many variables, i.e household income, expenditure, number of household members, and saving. All variables are scored, and be calculated as index. Refers to scoring and indexing result, condition of economic aspect in slums area is showed in Figure 8. Economic condition in slums area was dominated by moderate category, while proportion of good category placed in second rank, and the lastest isd bad category.

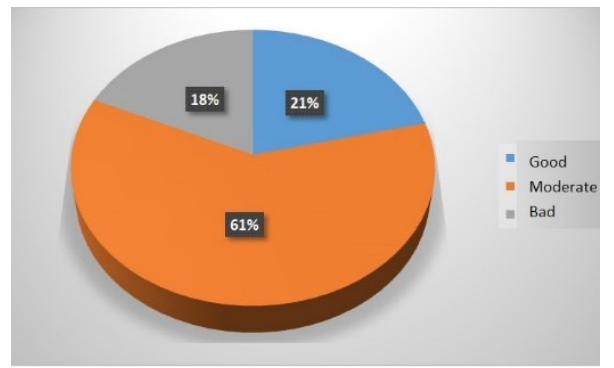

Fig 8. Proportion of Economic Aspect Condition

Spatial distribution of economic aspect in each "kelurahan" is showed in Figure 9. As happen in social aspect, it is also seen that bad cateory of environmental aspect spreaded dominantly in southern part of research area. Still associated wit 3 main rivers, "Kelurahan" which has bad cateogry of economic aspect are Notoprajan, Brontokusuman, Warungboto, and Prenggan. The others "kelurahan" which categorized into bad category of economic aspect in northen part is Gowongan.

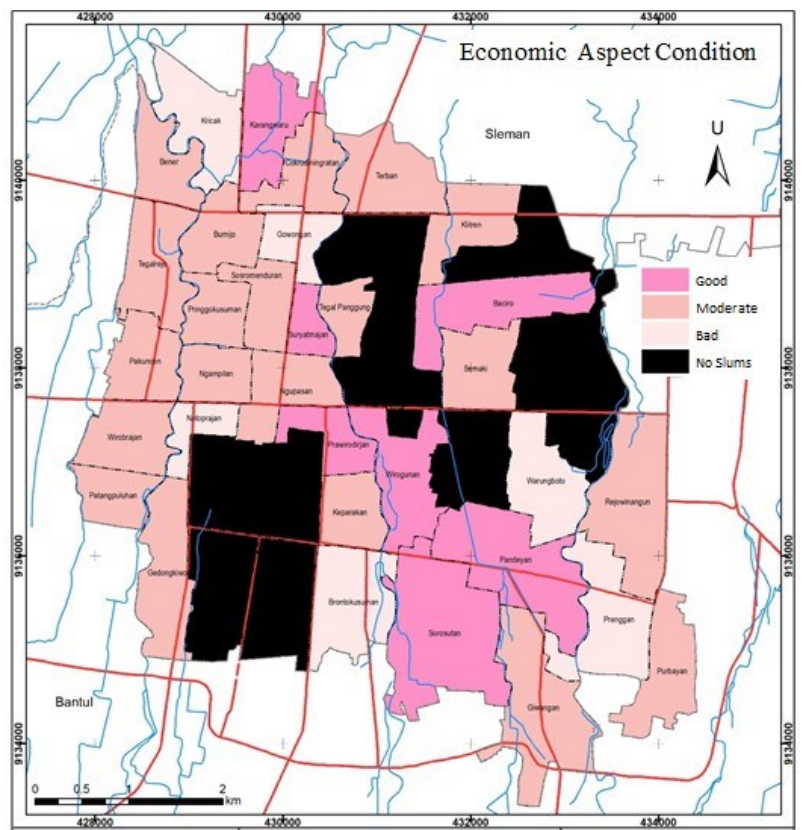

Fig 9. Spatial Distribution of Economic Aspect Condition

Refers to Rapoport, one issue related to slums is the management practices developed by the residents and their impact in relation to risk and natural disasters [11]. Thus, linking natural disaster occurrence with slums phenomenon is an interesting study. And in the end, how all stakeholders pay attention to slums management based 
on slums status and disaster vulnerability is appealing one.

Slums often associated with poor people, and vulnerable area as well. Quote to BPBD (Local Disaster Management Board) of Yogyakarta, majority of slums area are vulnerable site to natural disaster. In accordance with disaster occurrence in Yogyakarta City, there are 3 types of natural disaster took place in slums zones, they are floods, earthquake, and epidemic of desease.

Figure 10 shows spatial distribution of flood vulnerable zone in each "kelurahan" of Yogyakarta City. It is seen that spatial distribution of flood disaster vulnerability have close relation to slums area. The areas that categorized into high vulnerable of floods have high correspond to slums location. Some "kelurahan" that categorized into high vulnerable of flood disaster are Karangwaru, Cokrodiningratan, Gowongan, Terban, Kotabaru, Tegal Panggung, Pringgokusuman, Baciro, Sorosutan, Pandeyan, dan Warungboto. Majority of them have slums area closed to main river.

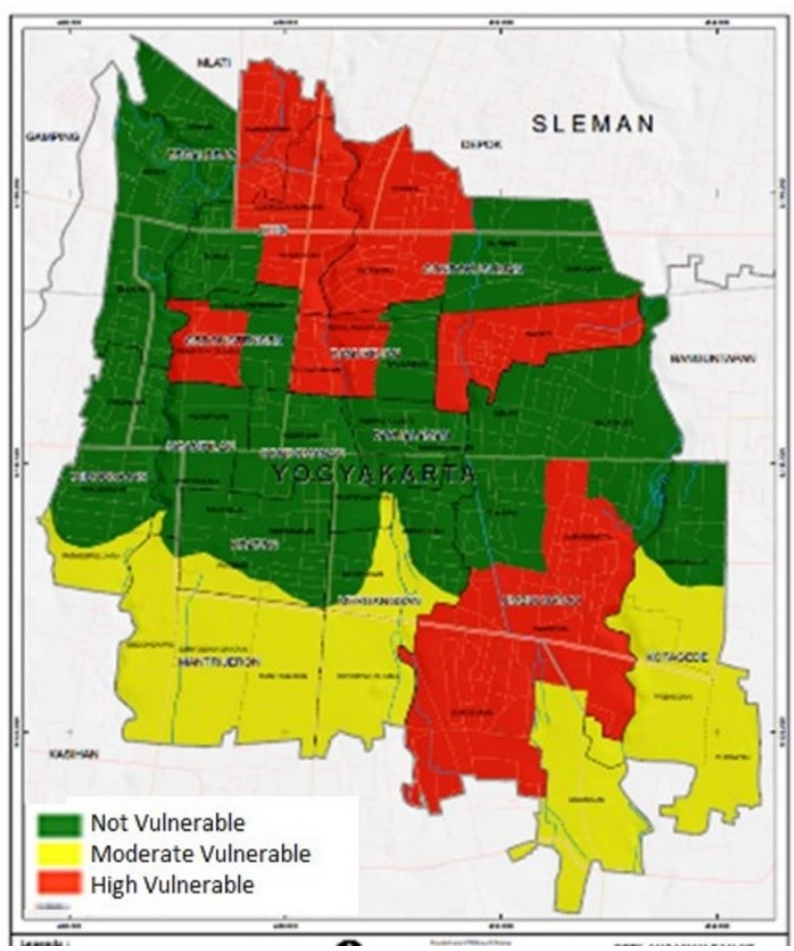

Fig 10. Spatial Distribution of Flood Vulnerable Zone

Another disaster that also frequent occurred, but actually did not had direct relation to slums area, is earthquke. In Yogyakarta City, earthquake can take place anywhere, not only happened in specific location. But, many experience evinced that there are a particular area more impacted than other site. Spatial distribution of earthquake disaster vulnerable area shows in Figure 11. Figure 11 shows that almost all of Yogyakarta City area are vulverable (high and very high) to earthquake hazard.

Moreover, epidemic of desease also often occurs in slums areas. Dengue fever, diarrhea, dysentery, and some infectious desease take place in slums area seasonaly. Figure 12 shows the vulnerability of epidemic of desase in Yogyakarta City.

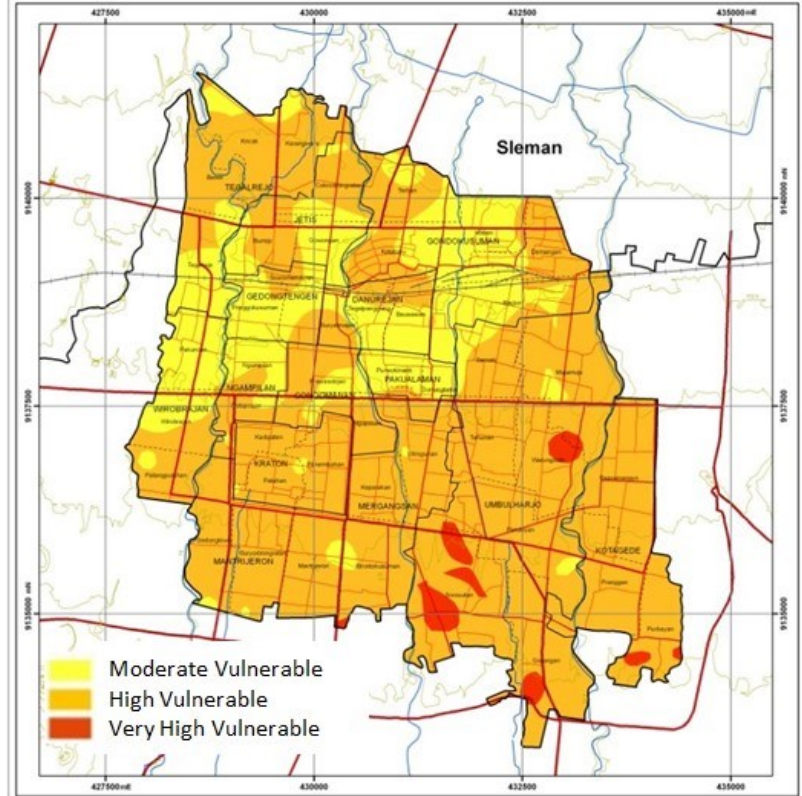

Fig 11. Spatial Distribution of Earthquake Vulnerable Zone

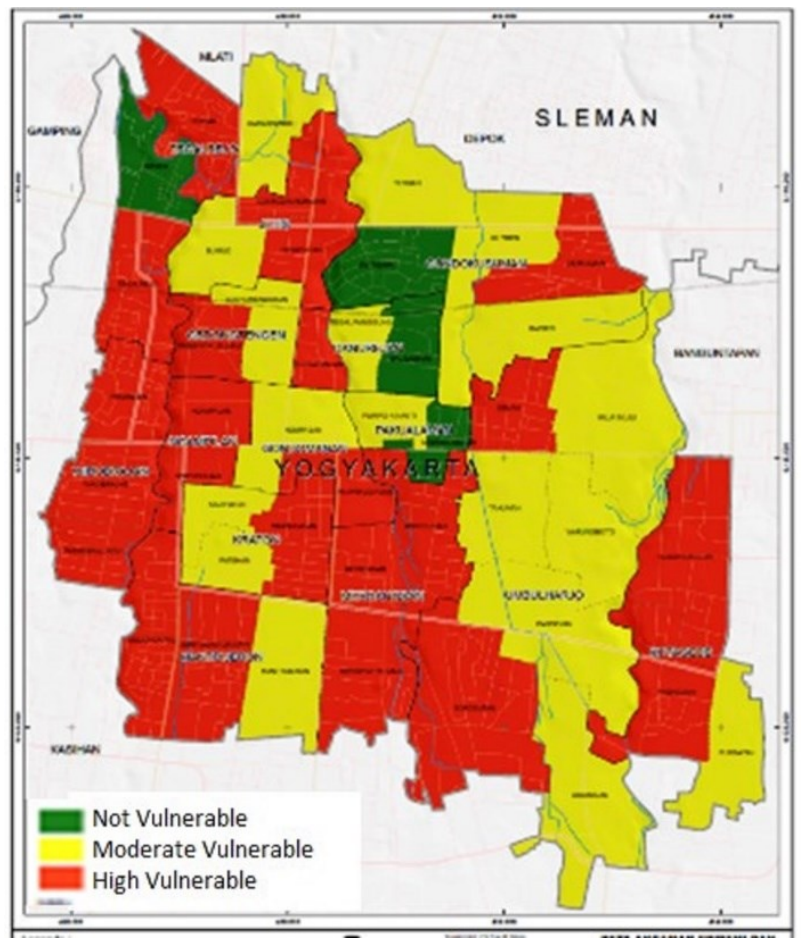

Fig 12. Spatial Distribution of Epidemic Desease Zone

Mostly, along three main rivers belongs to high vulnerable zone of epidemic of desease. Correspond to three disaster maps, it can conclude that there are high connection between slums zone and hazard potential zone. By merging all slums index maps and vulnerable zone maps, one single map that represent how slums are managed. Slums management grade map displays in Figure 13 


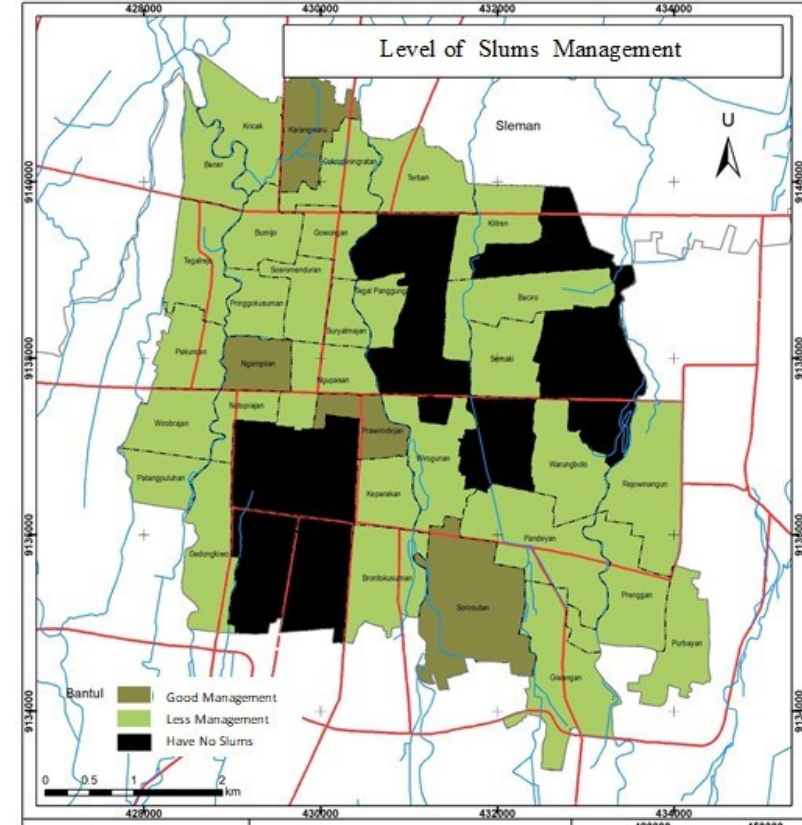

Fig 13. Spatial Distribution of Slums Management Grades

Four "kelurahan" successful to manage slums, they are Karangwaru, Ngampilan, Prawirodirjan, and Sorosutan. Field observation and indepth interview taken in this research gave an overview about how it happen. All of four "kelurahan" mentioned before, have very good social participation amongs citizens, great leadership, and well managed social organisation.

Some findings in this research are in accordance with previous study have done. Napier noted that the condition that exist in slums such as living under physical threat from disasters and improper housing have direct impats to slums dwellers [14]. This is mainly correspond to the low capacity of slums dwellers to cope from disaster, for instance floods and earthquake, compare with normal communities [16]

Good initiative from non-government organisation, good governance from local leaders, and good participation amongs people, respectively, can purchase slums improvement in a good way. If each of them can play role in the right position, creating responsible poor people is a necessity. Fekade noted that there are four major factors made slums upgrading approach unsuccessful, failed financial commitment, negative socio-economic respons, insecurity of tenure, and nonreplicability of best practices [17].

Similar to the terms stated by Fekade, financial commitment which depend on good leadership or good governance, play very important role in maintaining slums problems. Negative socio-economic respons of slums dwellers can be solved by encouraging good participation. And the last, Good initiative from nongovernment organisation can trigger the authority to provide security of tenure to helpless people.

However, this study also found out some misalignment with another previous study. Mahabir concluded that one main reason caused slums continued persistence is rural-to-urban migration [13]. In fact, net rural-to-urban migration in Yogyakarta City is low, even total population a bit decreased. Anyhow, slums area in Yogyakarta City always increased time by time. One argument that can be applied to explain this is that the ascending of slums is influenced by aging process. In other words, slums growth in Yogyakarta generated belongs to generated type.

From the perspective of Sustainable Development Goals, slums is one issue that have to be solved. Combining physical-spatial and socio-economic approaches is a smart choice to run. What experienced in Yogyakarta City can be used as a lesson learnt on how to manage slums in many variations.

\section{Conclusions}

Based on the results, it can conclude as follow:

(1) Slums in Yogyakarta City distributed mainly along three main rivers, and

(2) There are very closed association between slums area and disaster vulnerable zones.

Very high appreciation to Faculty of Geography which provide an opportunity to conduct this research, and to all of the informants involved in this research.

\section{References}

1. A. Ezeh, O. Oyebode, D. Satterwaite, Y.F. Chen, R. Ndugwa, J. Sartori, R.J. Lilford, The Lancet 389, 547-558 (2017)

2. WCED, Our Common Future (Oxford UP, 1987)

3. D. Marwasta, J. Forum Geografi 15 (1), 60-73 (2001)

4. UN-Habitat, The Challenge of Slum (Earthscan Pub Ltd, 2003)

5. B. Cohen, J. Techsoc 28, 63-80 (2006)

6. M. R. Montgomery, Science 319, 761-764 (2008)

7. S. Fox, On the origins and consequences of slums (Oxford, 2008)

8. S. F. Rashid, J. of Health, Population, and Nutrition, 27, 574-586 (2009)

9. S. V. Lall, M.K. Lundberg, and Z. Shalizi, J. Urban Ecconomics 63, 56-73 (2008)

10. S. Taschner, Designing the spaces of poverty (University Sao Paulo, 2001)

11. A. Rapoport, Spontaneous settlement as vernacular design, 51-77 (Temple Uni Press, 1988)

12. City Alliance, About slum upgrading (Washington DC, 2006)

13. R. Mahabir, A. Crooks, A. Croitoru, and P. Agouris, J. Regional Science, 3 (1), 737-757 (2016)

14. M. Napier, Informal settlement integration, (University of Montreal, 2007)

15. I. Ajibade and G. McBean, Geoforum, 55, 76-86 (2014)

16. A. Ebert, N. Kerle, and A. Stein, Natural Hazards, 48, 275-294 (2009)

17. W. Fekade, Habitat International, 24, 127-150 (2000) 